Локайчук, Світлана. «Мовний портрет Слуги з Добромиля за однойменним романом Галини Пагутяк». Лінгвостилістичні студї, вип. 11, 2019, с. 89-99.

Lokhaichuk, Svitlana. "Portrait of the Servant from Dobromil Based on the Cognominal Novel by Halyna Pahutiak". Linguostylistic Studies, iss. 11, 2019, pp. 89-99.

Удк 811.161.2'373.4'367:821.161.2'06.08Пагутяк

https://doi.org/10.29038/2413-0923-2019-11-89-99

\title{
МОВНИЙ ПОРТРЕТ СЛУГИ З ДОБРОМИЛЯ ЗА ОДНОЙМЕННИМ РОМАНОМ ГАЛИНИ ПАГУТЯК
}

\author{
Світлана Локайчук \\ Східноєвропейський національний університет імені Лесі Українки, \\ Луцьк, Україна
}

У статті розглянуто лексичні та лінгвостилістичні засоби творення мовного портрета міфічної істоти в людському тілі, дхампіра Слуги з Добромиля. Встановлено, що фізичний портрет головного персонажа твору подано лаконічно: серед соматичних ознак виділено лише очі, губи, волосся, вестизми найчастіше репрезентовані загальною номінатемою одежа. В описі невербальної поведінки акцент зроблено на незвичайній зворушливій усмішці Слуги. При творенні психологічного портрета, письменниця використовує низку лексичних засобів, які підкреслюють особливості характеру, темпераменту, настрою, світогляду. Мовленню головного героя властива афористичність. Цитати з Біблії, які становлять основу християнської етики, та їх трактування сприймаються як слогани індивідуальної філософії головного героя твору.

Ключові слова: персонаж, мовний портрет, психологічний портрет, опис зовнішності, лексико-стилістичні засоби.

\section{LINGUISTIC PORTRAIT OF THE SERVANT FROM DOBROMIL BASED ON THE COGNOMINAL NOVEL BY HALYNA PAHUTIAK Svitlana Lokhaichuk \\ Lesya Ukrainka Eastern European National University, Lutsk, Ukraine}

The portrait of a character, along with the descriptions of landscapes, interiors, monologues, and dialogues, is a part of the literary text structure, creating the artistic picture of the work. The issue of the language portrait is of great interest in modern linguistic and stylistic studies, and, mainly, due to the ambiguity of the term interpretations. We assume the language portrait of a character as a set of lexical and stylistic means involved by the author to describe the appearance, nonverbal characteristics, speech, character traits, thoughts dynamics, feelings, and experiences of the character. The purpose of the research is to analyze the lexical and stylistic means of creating a linguistic portrait of the main character from Halyna Pahutiak's novel The Servant from Dobromyl. The stylistic devices and expressive means used to describe appearance features are essential for the physical portrait of the character, the formulation of his value priorities - for the psychological portrait, and his social status - for the social portrait. All these aspects are organically combined in the novel by H.Pahutiak, in the image of the Servant - dhampir, a mythical creature in the human body. Lexical and linguistic-stylistic means play a significant role in the creation of the Servant's

(C) Локайчук С., Східноєвропейський національний університет імені Лесі Українки, 2019.

Це стаття відкритого доступу на умовах CC BY-NC 4.0 
linguistic portrait: repetitions, contextual synonyms, antonymous pairs, stylistic figures of antonomasia, antitheses, direct citation and reinterpretation of the biblical aphorisms. The main character in the work appears under several names - Servant, the Borrowed, Sower, Sylvester, which transmit information about his role-function, help to identify his status in society. The choice of a name is not just a formal act but also an element of the social-linguistic portrait of the character. The physical portrait of the protagonist of the novel is presented briefly. The somatic features are predominantly the descriptions of only eyes, lips, hair. Westisms are most often represented by the general nominatheme of clothing. In the description of the non-verbal behavior, the emphasis is on the unusual touching smile of the Servant. Creating the psychological portrait, the author uses a number of lexical means that accentuate the features of character, temperament, mood, or worldview. In the structure of emotional and value-related expressions, the nominations of oppositional rows dominate $(a$ loyal servant - bad servants, the generosity of the soul - the generosity of the purse, forgiveness/mercy - revenge). Synonyms with positive and negative connotations reinforce the emotional and semantic significance of the values inherent in the concept of worldview, which the Servant pursues. The protagonist's speech is rich in aphorisms. Quotes from the Bible, which reflect the fundamentals of Christian ethics, and their interpretation are apprehended as the ideas of the protagonist's individual philosophy. In general, the linguistic portrait of the Servant from Dobromyl absorbs a whole set of the features, dispersed in the novel.

Key words: character, language portrait, psychological portrait, description of appearance, lexical and stylistic means.

Вступ. Портрет персонажа поряд із описами пейзажів, інтер'єрів, монологами, діалогами входить до структури художнього тексту, формуючи художній світ твору. Проблема вивчення мовного портрета в сучасній лінгвостилістиці пов'язана 3 неоднозначністю інтерпретацій самого терміна, який на сьогодні не має однозначної дефініції. У короткому тлумачному словнику лінгвістичних термінів «Українська мова» термін мовний портрет визначено як стилістичну категорію, що реалізується у художній прозі, та містить «опис зовнішніх ознак персонажа, а також його внутрішнього (психологічний мовний портрет) стану, які забезпечують цілісність художнього зображення» (Єрмоленко, Бибик, і Тодор 94). На думку Т.Насалевич, у портретному описі втілюється авторське зображення зовнішніх характеристик та психологічних особливостей персонажа (6), оскільки портретний опис $\epsilon$ i засобом передавання внутрішнього стану, характеру людини.

За тематичним (змістовим) підходом П. Невська розрізняє три види мовних портретів у художніх текстах: 1) фізичний портрет, який розкриває фізіологічні особливості зображуваної людини - обличчя, руки, фігуру та інше; 2) соціальний портрет, який містить інформацію про статус людини у суспільстві, що реалізується через опис їі одягу, постави, моментів із щоденного життя; 3) духовний портрет, який передбачає опис ціннісних пріоритетів персонажа, мотивацію його дій, вчинків, а також те, як і про що він говорить (117). К. Писаренко дещо розширює та видозмінює цю класифікацію, виокремлюючи гендерний, фізичний, психологічний (характероцентричний), соціальний та мовленнєвий тип портрета персонажа (152). Г. Старикова виділяє власне портретний опис, для 
створення якого залучається соматична (лексеми на позначення тіла людини та його частин), вестиальна (номінації одягу, взуття), кінетична (назви міміки, жестів) лексика (5). На наш погляд, мовний портрет доцільно розглядати як сукупність лексико-стилістичних засобів, залучених автором для опису зовнішності, невербальних характеристик, мовлення, рис характеру, динаміки думок, почуттів, переживань персонажа.

Мета дослідження - аналіз лексико-стилістичних засобів творення мовного портрета головного персонажа роману Галини Пагутяк «Слуга 3 Добромиля».

Матеріал і методи дослідження. Матеріалом дослідження $\epsilon$ картотека лексем на позначення зовнішності та одягу, характеру, ціннісних пріоритетів головного персонажа роману Г. Пагутяк «Слуга 3 Добромиля», виданого 2006 року. У статті застосовано описовий метод для систематизації фактичного матеріалу; метод суцільної вибірки - для встановлення системи мовних одиниць, яким надає перевагу Г. Пагутяк для створення портретного опису Слуги; метод контекстуального аналізу для з'ясування семантичної структури опорних лексем; прийоми аналізу мовного матеріалу, його систематизації та інтерпретації.

Результати дослідження та дискусія. Творчість Галини Пагутяк самобутнє явище в сучасній українській прозі. Як слушно зазначає Т.Гребенюк, «фірмовим знаком» письменниці $€$ спроба художньо осмислити людську душу в ракурсі містичного бачення світу (106). Поява 2006 року роману «Слуга 3 Добромиля» відразу привернула увагу дослідників, передусім літературознавців (статті А.Артюх, Г. Бокшань, Я. Голобородька, . Левків, В.Неборака, К. Оселедько). Разом із тим лексико-стилістичні засоби, які використовує письменниця у змалюванні портрета головного героя, ще не були предметом аналізу.

Майже три четвертих тексту роману «Слуга 3 Добромиля» - це розповідь формально божевільного чоловіка 3 незвичним іменемсамоозначенням, «який мав багато імен, проте вперто називав себе Слугою $з$ Добромиля» (Пагутяк 123), про себе, про своє призначення, бачення подій і людей, які беруть у них участь. А. Артюх зауважує, що в цьому випадку «вибір імені $\epsilon$ ключовим моментом самоідентифікації головного героя у довколишньому світі» (16). «Хто ж він такий, цей незвичний божевільний, поціновувач i переписувач церковних книг, знавець греки, латини і кількох новіших мов, благодійник і торговець сіллю, слуга пана, який був найстаршим серед галицьких купців, а загинув від рук розбійників?» - запитує В. Неборак (207).

Слуга з Добромиля - дхампір (дитина мертвого опиря (упиря) i відьми), істота в людському тілі, що одночасно належать до реального світу людей та ірреального - надприродних сил. Його ще немовлям після страти-спалення матері-відьми врятували вовки, перенісши на дорогу, де дитину підібрала валка Купця з Добромиля, Старшого в Ордені Золотої 
Бджоли. Поєднання двох світів у романі - це зображення двох окремих реальностей, кожній з яких притаманні власні категорії світовиміру. Зокрема, лікар, який проводить сеанс психотерапії зі своїм пацієнтом, зауважує, що слово «слуга нагадує про нерівність та соціальне приниження» (Пагутяк 193), трактуючи лексему служити за значенням 'бути прислугою' (Словник 9: 379), проте Слуга спростовує цю репліку, сприймаючи свою функцію як особливу честь, та орієнтується на іншу сему: служити - 'бути відданим, вірним чому-небудь, якійсь справі' (Словник 9: 379), а таке служіння не принижує, а навпаки вивищує. На його думку, «бути слугою Купця з Добромиля $\epsilon$ більшою честю, ніж бути єпископом, чи боярином, або навіть князем» (Пагутяк 183).

Упродовж свого життя головний персонаж мав декілька імен, три 3 яких пов'язані з язичницькою традицією найменування людей - Слуга, Позичений, Сівач, а четверте Сильвестр - з християнською. Ці імена також несуть інформацію про його призначення. Знайдене на лісовій дорозі немовля Купець з Добромиля залишає на виховання (позичає) бездітній селянській родині на Перемишлянщині. Саме там його називають Позичений. Досягнувши семи років, хлопець отримує інше ім'я - Сівач, мотивоване його даром сіяти зерно так, що його не скльовували птахи (Г. Бокшань у цьому вбачає алюзію на Біблійну притчу про сівача, який поширює слово Боже, той, хто служить Богові (14)). У дев'ятирічному віці хлопчик був хрещений у монастирі Преображення села Спас, куди привів його ворожбит, та отримав ім'я Сильвестр, яким часто називали ченців. Воно походить від латинського silvester 'лісовий' (Скрипник, Дзятківська 99) i, очевидно, невипадкове, оскільки Купець знайшов немовля на лісовій дорозі. Такі «значущі» імена $\epsilon$ самостійним стилістичним прийомом, відомим як антономазія, тобто вид метонімії, надання додаткового наймення (за провідною рисою) (Святовець 25), що грунтується на одночасній реалізації двох типів лексичних значень - основного й контекстуального, предметно-логічного та власної назви (Андреева 5-6). Сукупність найменувань головного героя допомагає ідентифікувати його статус у соціумі, тобто ім'я $\epsilon$ не лише формальною ознакою, а й елементом соціального мовного портрета персонажа.

А. Ільяшевич та Н. Голікова вказують на те, що мовний портрет зазвичай «структурується через смислові поля, його елементи вичленовуються в різних фрагментах тексту, часто досить віддалених один від одного. Розпорошені в тканині твору описи утворюють своєрідну сітку, що $\epsilon$ основою побудови цілісного образу» (139). Формальною ознакою цієї єдності є вже саме ім'я дійової особи.

Виділяючи зовнішність як підставу для типологізації портретів, дослідники вирізняють соматичні (від грец. sōma 'тіло' - лексика на позначення обличчя, статури тощо), вестиальні (від лат. vestis 'одяг' назви одягу, аксесуарів), рухові, мовленнєві ознаки (Писаренко 152-153). У художніх текстах ці елементи фізичного мовного портрета зазвичай 
уживаються в комбінованому вигляді, хоча письменник може наголошувати на одній із характеристик. Зокрема, Г. Пагутяк так описує появу Слуги: «...він спершу не зауважив чоловіка, що самотньо стояв під величезним дубом ... Стояв собі вільно, притулившись спиною до дуба заклавши ногу за ногу. Був у самій картатій сорочці й сірих штанях...» (Пагутяк 33).

Незважаючи на те, що в романі подано нібито опис конкретного чоловіка, кожен у зовнішності Слуги бачить щось своє: «Отець Атаназій впізнав у тому чоловікові когось іншого: свого брата,... Таке ж високе чоло й брови, що зрослися у переніссі... Отцеві-настоятелеві незнайомець під дубом нагадав його товариша Юхима, зухвалого і веселого, якого не брала куля. Одному здалося, що у нього очі його матері, іншому він нагадав ивагра з Ляшок Мурованих, а діти впізнали у ньому нібито свого вчителя, що пропав...Попри різні візї̈, чоловік був молодий, близько тридияти літ» (Пагутяк 33-34). Мінливість обличчя головного героя пояснюють сказані ним слова: «Вniзнають не по обличчі, а по вчинках, як казав мені колись один добрий чоловік» (Пагутяк 74). Проте це не єдиний фізичний портрет Слуги - інший опис подано, коли герой спить і не може контролювати свого виразу обличчя: «У сні лище чоловіка втратило здатність змінюватись на догоду людям, й стало таким, що його важко запам'ятати: без різких акцентів. Під тонкими повіками ховались сірі очі, колір яких легко змінювався під впливом світла чи настрою, губи, з яких довго не зникала усмішка, довше, ніж треба, темне волосся з ледь помітною сивиною... Нічого особливого» (Пагутяк 36). Як бачимо, лаконічно змальовано очі, губи, волосся.

Зауважимо, що авторка майже не подає опису міміки головного героя. Виняток становить лише усмішка / посмішка (абсолютні синоніми у романі - С. Л.) - 'особливий порух м'язами обличчя (губ, очей)' (Словник 10: 491): «губи, з яких довго не зникала усмішка, довше, ніж треба» (Пагутяк 36). Проте усмішка Слуги особлива, це не вияв радості, задоволення, а зовсім протилежного - печалі, може, прихованого горя. Оповідаючи, про те, як жалібний подзвін сповістив про смерть князя, «Слуга з Добромиля сумно всміхнувся і якось наче розгублено подивися на Олексія Івановича» (Пагутяк 212). Ця незвичайна усмішка викликала прихильність Купця з Добромиля, який знайшов немовля. Розповідаючи про це, головний герой зазначає: «Коли над'їхала валка, я посміхався. Сміх не викликає співчуття, $а$, отже, й не обтяжує. Він зворушує більше, ніж плач» (Пагутяк 69). На особливий усміх Слуги звертає увагу і князь Лев Данилович: «Не знаю, що досі тебе берегло в Спасівському монастирі. Hi вже знаю! Твоя посмішка, від якої всередині в людини все перевертається від жалю» (Пагутяк 98).

Усмішка головного героя $€$ ознакою його відкритості, дитячої незахищеності: «Слуга з Добромиля засміявся дзвінким дитячим сміхом»; «Чудово! - посміхнувся той якоюсь світлою дитячою посмішкою, через 
що не хотілось йому докоряти». Письменниця характеризує дорослого Слугу - вже в тілі Луки - словами: «Муж зовні, дитя всередині, той, хто називав себе і завжди називатиме Слугою з Добромиля...» (Пагутяк 127).

Акцент на соматизмах очі й руки зроблено у розповіді Слуги про його дворічне перебування послушником у Лаврівському монастирі: «Я вбирав очима все, що міг віднайти в книжках, навчившись латини, грецької, а також мови угрів та ляхів. Руки мої стали білими й бруднилися лише чорнилом» (Пагутяк 112). Фразеологізмом вбирати очима 'дуже уважно дивитися, запам'ятовувати бачене' (Словник 1:300) та епітетом білі руки підкреслено потяг головного героя до навчання, книг, сумлінної розумової праці.

Лексико-тематична група «Одяг» у романі найчастіше репрезентована загальною назвою одежа: «У горішньому кінці Лаврова, у вербах коло потоку, знову з'явився незнайомець у запорошеній одежі» (Пагутяк 35); «Я був у монастирській одежі, щоб ніхто не прийняв мене за втеклого раба» (Пагутяк 119); «Решту одежі я виміняв на старе лахміття, за що мене нагодували» (Пагутяк 237). Пріоритет духовного, порівняно з матеріальним, виявляється у використанні зневажливих назв взуття: якісь постоли, взувачка. Наприклад, оповідаючи про те, як він підлітком був служкою у князя, Слуга кількома скупими словами описує себе: «Видно він зрозумів, що я не ласий до взувачки. Зрештою, я ходив босий, тільки взимку надягав якісь постоли, завжди завеликі на мою ногу» (Пагутяк 106). Номінації конкретних предметів одягу трапляються на початку роману, зокрема вказується, що незнайомець був одягнений у звичний для селян буденний одяг: картату сорочу та сірі штани, i наприкінці, коли Слуга, побачивши як молодиця оре весняну землю коровою, узяв у її донечки торбину і став розкидати зерно, а коли нивка була засіяна, «пішов на межу, взув чоботи й накинув чорну кирею до п'ят» (Пагутяк 223). Загалом, фізичний портрет головного персонажа твору подано лаконічно, майже без використання деталей. Це можна пояснити і тим, що розповідь ведеться від першої особи, і тим, що для головного героя пріоритетними $\epsilon$ не матеріальні, а духовні цінності.

Зображення внутрішнього світу героїв за допомогою відповідних лексико-стилістичних одиниць $\epsilon$ метою психологічного портретування персонажів. При творенні цього типу портрета, письменник використовує низку лексичних засобів, які номінують особливості характеру, темпераменту, настрою, світогляду тощо. На наш погляд, саме цей тип портрета $є$ «проекцією авторського ідіостилю, що віддзеркалює певною мірою світоглядні засади митця та його ставлення до описуваних дійових осіб» (Писаренко 151).

Серед мотивів роману «Слуга з Добромиля» чільне місце займає тема служіння як найвищого призначення людини. Місію служіння головний герой не лише розуміє як своє вроджене призначення, а й приймає та ототожнює з джерелом задоволення: «Я навчився дуже важливої речі: 
знаходити втіху у своєму служсінні, як це буває в родині» (Пагутяк 152). Для назви покликання головного героя Г. Пагутяк використовує віддієслівний іменник служіння, позначене в СУМі ремаркою урочисте, за одним із значень дієслова служити 'виконувати які-небудь обов'язки щодо когось' (Словник 9: 380).

Слуга з Добромиля зберігає вірність своєму господарю - Купцеві, називаючи себе вірним слугою (Пагутяк 210). Вірність виступає для нього однією з найвагоміших етичних категорій: «Я не можу бути нічиїм слугою, крім Купия з Добромиля» (Пагутяк 136). Привертає увагу те, що авторка передає бажання служити лише одній особі через неприйняття альтернативи. Для цього вона використовує відразу два засоби: заперечну частку не та заперечний займенник нічий.

Слузі з Добромиля доручено донести до читача думку, що «Onupi $\epsilon$ частиною природи, а ви, люди, вважаєте себе вінцем творіння, при цьому проповідуєте смирення і покору перед єдиним паном - Богом. Тому з вас погані слуги, себелюбні й заздрісні» (Пагутяк 91). Письменниця конкретизує поняття 'погані слуги' означеннями з негативною оцінкою себелюбні, заздрісні.

Відданість у служінні становить основну складову сенсу життя Слуги, інша ж його частина - місія рятування - йому відкривається після спілкування з Оленкою, сестрою переписувача Євангелія Мирона. Це друге призначення сформульоване як афоризм: «I відкрилося мені моє призначення: якщо врятувати хоча б одну істоту, то разом з нею врятуєш цілий рід - дітей, онуків і правнуків» (Пагутяк 253).

Світоглядну картину головного героя передано фарбами полярних відтінків, особливо в його роздумах про роль музики у злагодженості світу й людини: «Музика, яка лежить в основі гармонії світобудови, пане докторе. Ї̈̈ можна почути у собі й вийняти з себе» (Пагутяк 70-71). Проте музика, яку Слуга закликає видобувати з себе, може бути різною - i мелодією смерті, і колисковою, і «тріумфуючою мелодією життя» (Пагутяк 128). Однак мелодія життя не просто збалансовує світ, у якому звучить музика смерті, але й перемагає ії. Щоб передати контрасти світу Г. Пагутяк використовує антонімічні пари: життя $і$ смерть, світло $i$ темрява, жар і холод: «Я вірив, що така музика існує, як існують світло і темрява, жар і холод» (Пагутяк 135).

Своє призначення Слуга формулює так: «А ще мені треба багато чого робити, що випливає з мого статусу боржника: виправляти заподіяну кривду, пом'якшувати зло» (Пагутяк 64). Привертають увагу словосполучення виправляти кривду, пом'якшувати зло, тобто йдеться не про каральну місію, не про цілковите знищення зла, а лише про його врівноваження, бо зло присутнє у світі як умова існування добра. Головний герой висловлює своє ставлення до того, як влаштований світ: «Bтім, $я$ мало вірив у те, що сей світ можна очистити від гріха. Часом його стає більше, часом менше. Такий Закон. Світ очищається сам по собі» (Пагутяк 
228). Слуга характеризує себе 3 позицій свідомого доброчинства, використовуючи антоніми добро-зло: «...тільки хотів би бути добрим і не чинити нікому зла» (Пагутяк 140). Зрештою назву твору, що містить топонім Добромиль (похідний від імені Добромил, утвореного способом складання основ добрий і милий), можна розглядати як проголошення ідеї служити добру.

Несподівано трактується поняття помсти - слова прощення і помста виступають контекстуальними синонімами: «Можливо, прощення $i \epsilon$ правдива помста, бо найглибше потрясає душу» (Пагутяк 199). Особисто значущим для головного героя твору є вміння неодноразово прощати 'пробачати чию-небудь провину; виявляти поблажливість до когось' (Словник 7: 354): «Та я згадав слова Ісуса, що треба прощати сім по сім разів...» (Пагутяк 197).

Усамітнення, необхідне для самозаглиблення й самопізнання, усвідомлюється Слугою як важлива передумова пошуку сенсу життя, розуміння свого призначення. $\mathrm{y}$ монастирях йому подобались «обмеження, регламент, впорядкованість, можливість побути на caмomi» (Пагутяк 195). У наведеній цитаті три іменники з абстрактним значенням - обмеження, регламент, впорядкованість - об'єднані в синонімічний ряд, який реалізує сему 'порядок'. Із цим поняттям пов'язана теза про необхідність займати в суспільстві місце відповідно до своїх здібностей та покликання: «Був би я незмірно радий, якби кожен лишався на місці, призначеному його стану. Се - найважніша річ, особливо, коли йдеться про нинішні тривожні часи. Найменший переступ відгукнеться через віки» (Пагутяк 272).

Слуга підкреслює значущість книг у власному духовному зростанні, у формуванні його особистості: «Вони нагадують мені про бажання стати на ноги, не залишатись вічно лежати в пилюці посеред битого шляху людського життя» (Пагутяк 294). Антитезою, вираженою фразеологізмами: лежати (валятися) в пилюці - стати на ноги, компактно сформульовано вартісність освіти в житті.

Слуга змалечку виховувався на Біблії, яка була головною книгою його життя. Г.Бокшань звертає увагу на те, що біблійні приписи невід'ємна частина особистої етики головного героя (15). Знаковою виступає ідея любові до Бога й до ближнього, яку він сприймає як провідну настанову: «Я й слухав і читав Євангеліє, де сказано, що люди мають любити одне одного...» (Пагутяк 136-137). Наявність віри Слуга вважає запорукою внутрішньої гармонії, встановленню якої заважає страх: «Страх втратити не життя, а посаду, роботу, легальне становище у житті. Він береться з відсутності віри, яка робить людину сильною й видющою» (Пагутяк 80). У цьому фрагменті тексту слова страх і віра виступають контекстуальними антонімами, хоча «Словник антонімів» подає зовсім інші пари слів з протилежним значенням: страх - відвага, віра - зневіра. Спостерігаємо ще одне протиставлення зі словесно 
невираженим другим компонентом, яке прочитується в підтексті: якщо віра «робить людину сильною й видющою», то, відповідно, страх, - слабкою і сліпою.

Протиставлення людського і божественного, на нашу думку, можна розглядати, як антитезу тіла і душі - щоденної метушні і вічності. Традиційне протистояння духовного й матеріального відтворено в афористичних за звучанням словах головного героя: «... щедрість душі потрібна більше, ніж щедрість калитки» (Пагутяк 246).

К. Оселедько зазначає, що мовленню головного героя притаманні афористичність і дидактичні інтонації (251). У різноманітних життєвих ситуаціях він принагідно цитує слова 3 Писання, які сприймаються як слогани його індивідуальної філософії: «Я теж посміхнувся, але нічого не сказав, бо страшне не те, що входить у наші вуха, а що виходить 3 наших yсm» (Пагутяк 148). Причини зла Слуга вбачає в порушенні законів природи, закладеного Богом порядку речей. Фундаментальні етичні категорії добро $і$ зло трактуються ним як полярно спрямовані вектори вибору людини та результати цього вибору: «Одне зло спричиняє інше, так само, як невелике добро переростає у велику благодать» (Пагутяк 90). Загалом, життя Слуги підпорядковане чітким духовним орієнтирам 3 Євангелія, які допомагають йому підтримувати згадувану ним гармонію зі світом. Виходячи 3 власного досвіду пізнання, він розширює цитату 3 Біблії, надає їй оригінального трактування: «Коли Царство Божсе всередині нас, то воно і скрізь» (Пагутяк 274).

Висновки та перспективи досліджень. Сукупність зображувальновиражальних засобів, які використовуються під час опису зовнішніх ознак, визначальні для фізичного портрета персонажа, формулювання ціннісних пріоритетів - для психологічного портрета, а суспільного статусу соціального. Усі ці аспекти в зображенні Слуги - дхампіра, міфічної істоти в людському тілі в романі Г. Пагутяк органічно поєднуються. У творенні мовного портрета Слуги значну роль відіграють лексичні та лінгвостилістичні засоби: повтори, контекстуальні синоніми, антонімічні пари, стилістичні фігури антономазї, антитези, пряме цитування i переосмислення біблійних афоризмів. Головний персонаж у творі виступає під декількома іменами - Слуга, Позичений, Сівач, Сильвестр, які допомагають ідентифікувати його статус у соціумі та слугують елементом соціального мовного портрета.

Фізичний портрет головного героя твору подано лаконічно: серед соматичних ознак виділено лише очі, губи, волосся, вестизми найчастіше репрезентовані загальною номінатемою одежа. В описі невербальної поведінки акцент зроблено на незвичайній зворушливій усмішці Слуги.

Для увиразнення психологічного портрета письменниця використовує низку лексичних засобів, які підкреслюють особливості характеру, темпераменту, настрою, світогляду. У структурі емоційноціннісних виразів переважають номінації у вигляді опозитивних рядів: 
вірний слуга - погані слуги, щедрість душі - щедрість калитки, прощення помста. Синоніми з позитивною та негативною конотацією підсилюють емоційно-смислову значущість цінностей, властивих концепції світобачення, якої дотримується Слуга. Мовленню головного героя властива афористичність. Цитати 3 Біблії, які становлять основу християнської етики, та їх трактування сприймаються як слогани індивідуальної філософії головного героя твору. Загалом, мовний портрет Слуги з Добромиля вбирає в себе всю сукупність розпорошених у творі характеристик головного персонажа, забезпечуючи цілісність образу.

У подальших дослідженнях можна здійснити порівняльний аналіз лексико-стилістичних засобів художнього опису персонажів в інших творах Г. Пагутяк як вияв мовомислення й естетичних уподобань письменниці.

\section{Список використаної літератури}

Андреева, Л. Лингвистическая природа и стилистические функции «значащих» имен (антономасии). Автореф. дисс... канд. филол. наук. Москва, 1965.

Артюх, Аліна. «Про самотність котів та опирів». Книжник, № 4 (134), 2007, с. 16-7.

Бокшань, Галина. «Аксіологічні домінанти християнської етики в романі Г. Пагутяк “Слуга з Добромиля"». Наукові праці Чорноморського державного університету імені Петра Могили комплексу «Києво-Могилянська академія». Серія: Філологія. Літературознавство, т. 192, вип. 180, 2012, с. 14-7.

Гребенюк, Тетяна. «Г. Пагутяк “Урізька готика" в контексті сучасної української літературної містики». Питання літературознавства, вип. 83, 2011, с. 106-12.

Єрмоленко, Світлана, Бибик Світлана, і Тодор, Олена. Українська мова: короткий тлумачний словник лінгвістичних термінів. Київ: Інститут української мови НАН України, 2009.

Ільяшевич, А., і Голікова, Н. «Ізотопія тексту та мовний портрет як одна з форм їі реалізації (на матеріалі роману П. Загребельного “Диво”)». Український смисл, № 1,2014 , c. $130-40$.

Насалевич, Тамара. Портретний опис у різних видах тексту. Автореф. дис. ...канд. філол. наук: 10.02.04. Одеса, 2002.

Неборак, Віктор. «Слуга опиря з Добромиля. Спроба переказу». Критика прози: статті та есеї. Київ: Грані-Т, 2011, с. 206-24.

Невская, Полина. «Структурно-типологические особенности портретных описаний в художественном произведении». Культурная жизнь юга Росии, № 4 (33), 2009, c. $115-7$.

Оселедько, Катерина. «Конфлікт демонічності та християнської етики у творчості Г. Пагутяк». Гуманітарна освіта у технічних вищих навчальних закладах, вип. 26, 2012, с. 245-55.

Пагутяк, Галина. Слуга з Добромиля. Київ : Дуліби, 2006.

Писаренко, Катерина. «Типологія мовних портретів персонажів у художніх текстах триптиху "Хресна проща" Р. Іваничука: змістовий аспект». Лінгвістичні дослідження, вип. 42, 2016, с. 150-5.

Святовець, Віталій. Словник тропів і стилістичних фігур. Київ : ВЦ «Академія», 2011.

Словник української мови, за ред. І. К. Білодіда. В 11 т. Київ: Наукова думка, 1970-1980.

Скрипник, Лариса, Дзятківська, Ніна. Власні імена людей: словник-довідник. Київ : Наукова думка, 1996.

Старикова, Г. Лексика портретных описаний. Автореф. дисс. ... канд. филол. наук: 10.02.01. Ленинград, 1985. 


\section{References}

Andreeva, L. Lingvisticheskaja priroda i stilisticheskie funkcii «znachashhih» imen (antonomasii). PhD Thesis Abstract. Moskva, 1965.

Artiukh, Alina. "Pro samotnist kotiv ta opyriv". Knyzhnyk, no. 4 (134), 2007, pp. 16-7.

Bokshan, Halyna. "Aksiolohichni dominanty khrystyianskoi etyky v romani H. Pahutiak "Sluha z Dobromylia"”. Naukovi pratsi Chornomorskoho derzhavnoho universytetu imeni Petra Mohyly kompleksu "Kyievo-Mohylianska akademiia". Seriia: Filolohiia. Literaturoznavstvo, vol. 192, iss. 180, 2012, pp. 14-7.

Hrebeniuk, Tetiana. "H. Pahutiak "Urizka hotyka" v konteksti suchasnoi ukrainskoi literaturnoi mistyky". Problems of literary criticism, iss. 83, 2011, pp. 106-12.

Yermolenko, Svitlana, Bybyk Svitlana, and Todor, Olena. Ukrainska mova: korotkyi tlumachnyi slovnyk linhvistychnykh terminiv. Kyiv: Instytut ukrainskoi movy NAN Ukrainy, 2009.

Iliashevych, A., and Holikova, N. "Izotopiia tekstu ta movnyi portret yak odna $\mathrm{z}$ form yii realizatsii (na materiali romanu P. Zahrebelnoho "Dyvo")". Ukrainian sense, no. 1, 2014, pp. 130-40.

Nasalevych, Tamara. Portretnyi opys u riznykh vydakh tekstu. PhD Thesis Abstract. Odesa, 2002.

Neborak, Viktor. "Sluha opyria z Dobromylia. Sproba perekazu”. Krytyka prozy: statti ta esei. Kyiv: Hrani-T, 2011, pp. 206-24.

Nevskaya Polina. "Structural-typological peculiarities of portrait representations in fiction". Kul'turnaja zhizn' juga Rosii, no. 4 (33), 2009, pp. 115-7.

Oseledko, Kateryna. "Conflict demonic and christian ethics in creativity by Pahutyak G". Humanitarian Education in Technical Universities, iss. 26, 2012, pp. 245-55

Pahutiak, Halyna. Sluha z Dobromylia. Kyiv : Duliby, 2006.

Pisarenko, Kateryna. "The Thematic Typology of Linguistic Portraits of Characters in Literary Texts of Triptych "Cross Pilgrimage" by R. Ivanychuk". Lingvistichni doslidzhennja, iss. 42, 2015, pp. 150-5.

Sviatovets, Vitalii. Slovnyk tropiv i stylistychnykh fihur. Kyiv : VTs “Akademiia”, 2011.

Slovnyk ukrainskoi movy, edited by I. K. Bilodid. 11 vols. Kyiv: Naukova dumka, 1970-1980.

Skrypnyk, Larysa, Dziatkivska, Nina. Vlasni imena liudei: slovnyk-dovidnyk. Kyiv: Naukova dumka, 1996.

Starikova, G. Leksika portretnyh opisanij. PhD Thesis Abstract. Leningrad, 1985.

Стаття надійшла до редколегії 12.08.2019 